\title{
Ideology Affects Trust in Science Agencies During a Pandemic
}

\section{Lawrence C. Hamilton and Thomas G. Safford}

The Carsey Perspectives series presents new ways of looking at issues affecting our society and the world. Any opinions, findings, and conclusions or recommendations expressed in this material are those of the authors and do not necessarily reflect the views of the sponsors or publisher.

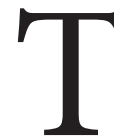

The extent to which governments and individuals respect the recommendations of science and science-based public agencies is having an enormous effect on the impact of COVID-19. Governments' respect for science affects whether they help provide sufficient testing, take aggressive enough action to reduce person-to-person transmission, assure the availability of health care, and move to contain the economic harm. Individuals' respect for science can impact whether they practice social distancing and enhanced hygiene.

Respect for science, however, has been politicized in the United States-especially since the 2016 election.

Public response to a question about the Zika virus pandemic, from a nationwide survey conducted by Carsey School researchers immediately after the 2016 U.S. elections, illustrates how political ideology affects trust in science-based agencies. The Zika virus pandemic had recently drawn international concern, so our survey included questions on this topic. ${ }^{1}$ One asked about trust in information from agencies such as the Centers for Disease Control (CDC), the premier national health science agency tasked with responding to epidemics: ${ }^{2}$

As you may or may not know, in 2015 an outbreak of Zika virus began in Brazil and spread to other countries in Latin America and the Caribbean. There are now some cases inside the United States. The next questions ask for your own views about this virus. As a source of information about the Zika virus, would you say that you trust, don't trust, or are unsure about science agencies such as the Centers for Disease Control (CDC) that study infectious diseases?

Figure 1 plots the results: 73\% said they trusted science agencies for information about the Zika virus. That was also the majority opinion among most subgroups on the survey, but with significant variations.

\section{FIGURE 1. DO YOU TRUST SCIENCE AGENCIES SUCH AS CDC THAT STUDY INFECTIOUS DISEASE, AS A SOURCE OF INFORMATION ABOUT THE ZIKA VIRUS?}

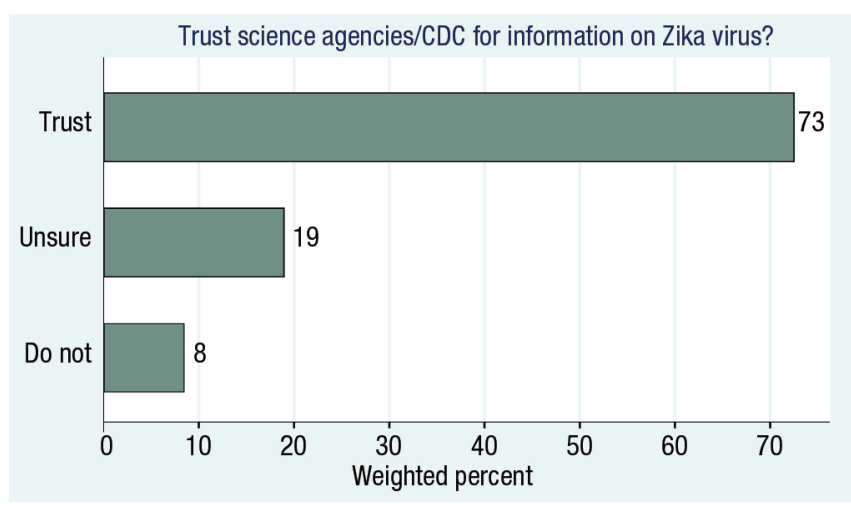

Source: Nationwide POLES survey, 2016

FIGURE 2. PERCENT WHO TRUST SCIENCE AGENCIES SUCH AS CDC FOR INFORMATION ABOUT ZIKA VIRUS, BROKEN DOWN BY 2016 PRESIDENTIAL VOTE (A) OR IDEOLOGY (B).

Trust science agencies/CDC for info on Zika virus, by vote and ideology

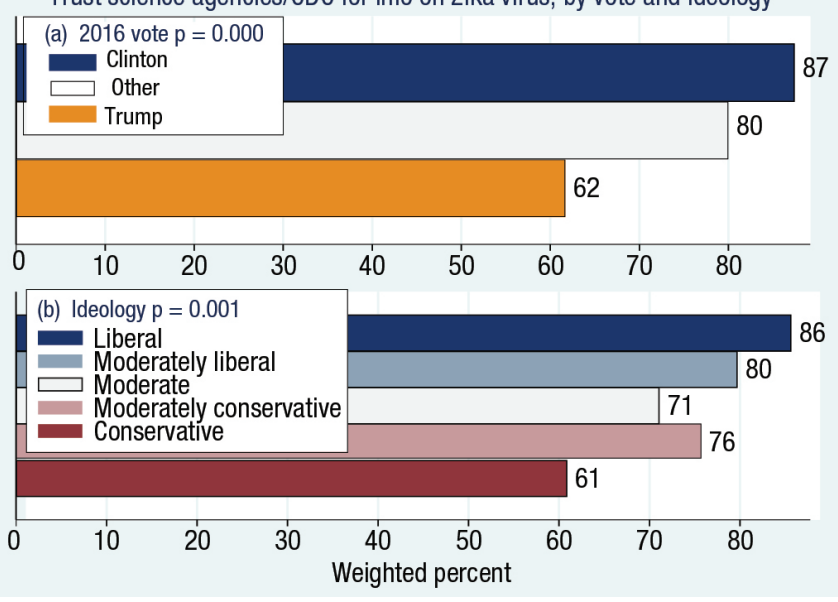

Source: Nationwide POLES survey, 2016

Figure 2a shows a 25-point gap between the views of respondents who voted for Hillary Clinton (87\% trust the CDC) and those who voted for Donald Trump (62\% trust the CDC). Figure $2 \mathrm{~b}$ depicts another 
25-point gap, between liberals and conservatives $(86 \%$ vs. $61 \%)$. Previous surveys had noted conservatives' lower trust regarding other science topics. ${ }^{3}$ The 2016 results in Figure $2 \mathrm{~b}$ depict political outlooks affecting trust in science-based agencies during a pandemic.

Political decisions since 2016 undermined U.S. preparedness for new pandemics, which becomes urgently relevant today. These decisions have affected the flow and openness of communication from federal science agencies, the organization of government actions, and the need to raise broad societal support for painful but science-informed responses to COVID-19. Ideological views are also affecting individual responsiveness to recommendations of scientific agencies which can have an important impact on the spread of COVID-19.

Some countries have responded differently. Facing waves of infection and epidemiological evidence, their governments acted on scientific recommendations, taking drastic measures to limit travel, public gatherings, and movements outside the home. Such actions signaled the importance of rapid science-based responses. These measures bought time for other countries that did not yet have as many cases, but not all of them used the warning time effectively. The U.S. government was notably slow to react, as the lack of a science-based approach commensurate to the scale of the pandemic left the country unprepared. By early March, South Korea had performed more than 200,000 tests for the virus, while in the United States limited supplies and restrictive rules on who could be tested held the number below $10,000^{4}$ despite pleas from medical workers and experts. ${ }^{5}$

The lack of a science-based U.S. response was a further manifestation of the Trump administration's dismantling of Obama-era programs for disease security, such as removing in 2018 a National Security Council officer and his team responsible for pandemics. ${ }^{6}$ Also in 2018, the Centers for Disease Control (CDC) faced the first of several budget cuts aimed at its diseasesecurity programs. ${ }^{7}$ In February 2020, as COVID-19 was spreading around the world, President Trump proposed cutting the CDC budget a further 19 percent. $^{8}$

\section{Endnotes}

1. Safford, T.G., L.C. Hamilton \& E.H. Whitmore. 2017. "The Zika virus threat: How concerns about scientists may undermine efforts to combat the pandemic." Durham, NH: Carsey School of Public Policy. http://scholars.unh.edu/ carsey/299/
2. Safford, T.G., E.H. Whitmore \& L.C. Hamilton. 2019. "Questioning scientific practice: Linking beliefs about scientists, science agencies, and climate change." Environmental Sociology 6(2):194-206. doi: 10.1080/23251042.2019.1696008

3. Hamilton, L.C., J. Hartter \& K. Saito. 2015. "Trust in scientists on climate change and vaccines." Sage Open. doi: 10.1177/2158244015602752; Hamilton, L.C. 2015. "Conservative and liberal views of science: Does trust depend on topic?" Durham, NH: Carsey School of Public Policy. http://scholars.unh.edu/carsey/252/

4. "Coronavirus testing: Criteria and numbers by country." https://www.worldometers.info/coronavirus/covid-19-testing/

5. Rabin, R.C., K. Sheikh \& K.Thomas. 2020. "As coronavirus numbers rise, C.D.C. testing comes under fire." New York Times, March 2 (updated March 10) https://www.nytimes. com/2020/03/02/health/coronavirus-testing-cdc.html

6. Sun, L.H. 2018. "Top White House official in charge of pandemic response exits abruptly," Washington Post, May 10. https://www.washingtonpost.com/news/to-your-health/ wp/2018/05/10/top-white-house-official-in-charge-ofpandemic-response-exits-abruptly/

7. Morris, C. 2020. “Trump administration budget cuts could become a major problem as coronavirus spreads." Fortune, February 26. https://fortune.com/2020/02/26/coronaviruscovid-19-cdc-budget-cuts-us-trump/

8. Mole, B. 2020. "Amid coronovirus outbreak, Trump proposes slashing CDC budget." Ars Technica, February 11. https://arstechnica.com/science/2020/02/amid-coronavirusoutbreak-trump-proposes-slashing-cdc-budget/

\section{See related publications at carsey.unh.edu}

The Zika Virus Threat: How Concerns about Scientists May Undermine Efforts to Combat the Pandemic (March 2017) Conservative and Liberal Views of Science: Does Trust Depend on Topic (September 2015)

\section{Acknowledgments}

Support for the 2016 POLES survey was provided by the PoLAR Partnership grant from the National Science Foundation (DUE-1239783), with additional help from the New Hampshire EPSCoR Safe Beaches and Shellfish project (IIA-1330641), and from the Office of the Senior Vice Provost for Research at UNH.

\section{About the Authors}

Lawrence C. Hamilton is professor of sociology and senior fellow at the Carsey School of Public Policy at the University of New Hampshire. Thomas G. Safford is associate professor of sociology and faculty fellow at the Carsey School of Public Policy. 